Article

\title{
New Oxindole-Bridged Acceptors for Organic Sensitizers: Substitution and Performance Studies in Dye-Sensitized Solar Cells
}

\author{
Yogesh S. Tingare ${ }^{1, *}$, Chaochin Su ${ }^{1, *}$, Ming-Tai Shen ${ }^{2}$, Sheng-Han Tsai ${ }^{1}$, Shih-Yu Ho ${ }^{1}$ \\ and Wen-Ren $\mathrm{Li}^{2, *}$ \\ 1 Institute of Organic and Polymeric Materials/Research and Development Center for Smart \\ Textile Technology, National Taipei University of Technology, Taipei 10608, Taiwan; \\ kieferboy8@hotmail.com (S.-H.T.); stacy760414@hotmail.com (S.-Y.H.) \\ 2 Department of Chemistry, National Central University, Chung-Li 32001, Taiwan; moodplayer@hotmail.com \\ * Correspondence: yogeshtingare@yahoo.co.in (Y.S.T.); f10913@mail.ntut.edu.tw (C.S.); \\ ch01@ncu.edu.tw (W.-R.L.)
}

Received: 5 April 2020; Accepted: 3 May 2020; Published: 5 May 2020

check for updates

\begin{abstract}
New D- $\pi$-A configured organic sensitizers featuring halogen-substituted oxindole-bridged acceptor units have been synthesized for dye-sensitized solar cells applications. Among fluorine, bromine, and iodine substitution, the cell based on bromine incorporated dye exhibited the highest efficiency. The oxindoles in these sensitizers were found to assist the electron injection through the chelation of their amide carbonyl groups to the $\mathrm{TiO}_{2}$ surface. This study provides an alternate approach for future rational dye design to gain excellent DSSC performance.
\end{abstract}

Keywords: oxindoles; halogens; electron injection; dye-sensitized solar cells

\section{Introduction}

Energy harvesting directly from the sunlight using the photovoltaic technology is being increasingly recognized as an essential strategy for future global energy production [1]. Finding energy generating devices using inexpensive and environment-friendly materials has become a well-focused academic and industrial research topic. The solar-to-power converting assembly, known as dye-sensitized solar cells (DSSCs), introduced by O'Regan and Grätzel has attracted a significant amount of attention [2-15]. The technology has shown a great potential to assist as an efficient, low production cost, and clean energy source. To achieve excellent solar power conversion efficiencies in DSSCs, considerable attention has been focused on designing and synthesizing various photosensitizers [10,11,16-20]. For the past decades, the sensitizers like ruthenium (II) polypyridyl complexes [21-27] and zinc-based porphyrin dyes [28-33] have dominated DSSCs as efficient sensitizers with their outstanding power conversion efficiencies. But the cost, toxicity and limited availability of the metals, as specially the ruthenium, have inspired researcher to pursue alternative sensitizing dyes for DSSC. Parallelly, the ongoing research on perovskite solar cells [34,35] is found to be promising with efficiency exceeding over $20 \%$. But the use of environmentally harmful lead-based materials and instability in these devices have raised some major concerns [36,37]. On the other hand, the metal free organic dyes have kept a considerable interest with their robust availability, flexibility of structural tuning, and high molar extinction coefficients which make them competitive alternatives to the other sensitizers [38,39].

Typically, metal-free organic dyes are configured with donor- $\pi$-bridge-acceptor structures. As per the literature reports, in-depth studies have been directed towards the modification of the donors and the $\pi$-bridge moieties of the organic dyes but only a few developments were made in the acceptor groups [10,40-42]. The most commonly used acceptors (anchoring groups) are carboxylic acid 
or cyanoacrylic acid [9]. But the cyanoacrylic acid acceptor was reported to exhibit some disadvantages, such as lower photostabilities due to presence of double bond and dominating redox properties because of strong electronegative nitrile moiety [43]. It was also reported that the nitrile group of the cyanoacrylic acid affected the acidity of the adjacent carboxylic acid which can give a negative influence on the binding to the $\mathrm{TiO}_{2}$ surface [44,45]. Several attempts have been made to replace the strong electron-withdrawing cyano group and construct new acceptor systems to achieve high absorptivity and good photostability [46-49]. The acceptor moiety of the dye shows a significant influence on the spectral response and the device performance. Therefore, there is a need to further explore various acceptors and expand "design principles" to help guide metal-free dye discovery.

The oxindoles are natural indole alkaloids and can be isolated from the plants [50]. Although oxindoles are ubiquitous within the pharmaceutical industry [51-53], the potential of oxindoles to act as sensitizing materials [54] has not been investigated by other groups and need to be studied thoroughly. We unprecedentedly visualize oxindoles as new acceptors for the organic sensitizers. It is our speculation that the amide group of the oxindole dye will not only act as an electron acceptor but also can direct the electron injection because of its chelation to the $\mathrm{TiO}_{2}$ surface [54]. Furthermore, it is located near the anchoring group which will help to accelerate the electron transfer to the $\mathrm{TiO}_{2}$ due to the shorter distance. The non-conjugated carboxylic acid group incorporated in the end of the dye will act as efficient binding group without affect the push-pull capability of the acceptor. Effect of halogens substituted on the donor moiety of the dye was also studied and was found to effectively contribute to the enhancement of the open-circuit voltage and the overall cell efficiency [55].

In this article, we designed and synthesized a series of new oxindole sensitizers (TI111-TI116, Figure 1a) which exhibited respectable photoelectric conversion efficiencies $(\eta)$. These sensitizers have an excellent electron-donating triphenylamine (TPA) donor and the thiophene in the spacer and are differentiated by various halogen-substituted oxindole acceptors. The electronegative fluorine (F) element is well known for its application in the field of organic light-emitting diodes as well as in the artificial amino acid synthesis [56-60]. The alteration in the Fermi levels of the dye could be achieved by using F substituent in the acceptor of the dye, which usually accounts for an increase in the open-circuit voltage of the dye by reducing the dark current [58]. We incorporated an $\mathrm{F}$ atom in the parent compound TI111, forming TI112, to alter the photo-physical properties of the oxindole dye. The comparative studies of different halogen substituents in the donor part of sensitizers have been evaluated [55], but their effects on the sensitizing properties of dyes when substituted near the acceptors have not been reported. Therefore we further extended our investigation and designed TI114, and TI115 in which bromine (Br), and iodine (I) substituents were incorporated, respectively. Additionally, it is noted that the variation in the position of the substituent with respect to the anchoring group can deliver different cell performances [58]. Thus, we designed TI114 analogue, TI116, to study the effect of position of the substitution on the conversion efficiency of the DSSC.

a)

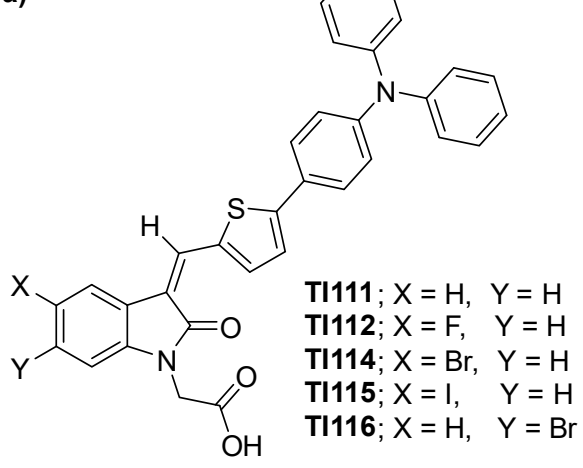

b)

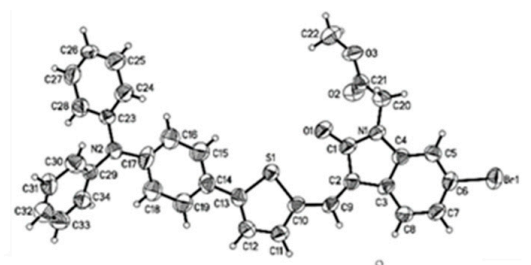

c)

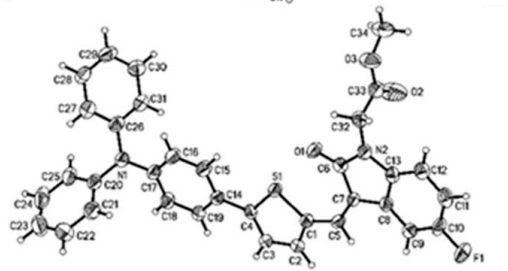

Figure 1. (a) Molecular structures of oxindole dyes (TI111-TI116). (b) ORTEP diagram of methyl ester of TI112. (c) ORTEP diagram of methyl ester of TI116. 


\section{Results and Discussion}

Scheme 1 depicts the syntheses of new sensitizers TI111-TI115 that started with a Knoevenagel condensation reaction using amides 1a-d and 5-[4-(diphenylamino)phenyl]thiophene-2-carbaldehyde (2) [54] to yield condensed compounds $\mathbf{3 a - d}$ as single Z-isomers. Oxindoles $\mathbf{3 a}-\mathbf{d}$ were then alkylated with methyl bromoacetate in the presence of base and tetrabutylammonium bromide (TBAB) to afford esters 4a-d. Finally, sensitizers TI111-TI115 were obtained after basic hydrolysis of their corresponding esters. As shown in Scheme 2, the preparation of the sensitizer TI116 began with a microwave-assisted Wittig reaction. 6-Bromo- $1 \mathrm{H}$-indole-2, 3-dione (5), aldehyde $2, \mathrm{PPh}_{3}$, and toluene were combined in a microwave reaction vessel and irradiated in the Synthos 3000 microwave oven at $300 \mathrm{~W}$ for $4 \mathrm{~h}$ to yield the desired product $\mathbf{6}$. Ester 7 was synthesized through alkylation of compound $\mathbf{6}$ with methyl bromo acetate. Basic hydrolysis of the resulting ester 7 successfully provided the required sensitizer TI116. The molecular geometries of TI112 and TI116 dyes were confirmed through single-crystal structural analysis of their corresponding esters $4 \mathbf{b}$ and 7, respectively (Figure 1b,c; Tables S1 and S2 in the Supporting Information). As shown in the X-ray structures, the stereogenic double bonds present in oxindoles are arranged in $\mathrm{Z}$ configuration.

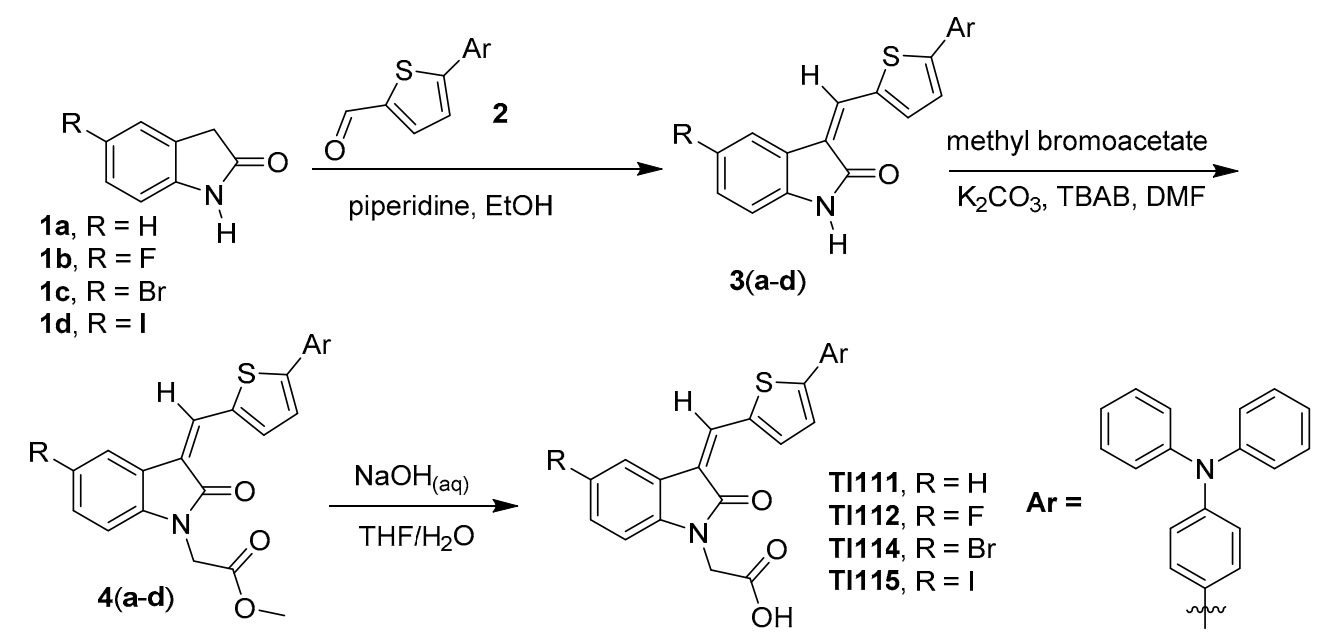

Scheme 1. Synthesis of TI111-TI115 sensitizers.<smiles>O=C1Nc2cc(Br)ccc2C1=O</smiles><smiles>COC(=O)CN1C(=O)/C(=C\c2ccc(Br)s2)c2ccc(Br)cc21</smiles><smiles>O=C(O)CN1C(=O)/C(=C\c2ccc(Br)s2)c2ccc(Br)cc21</smiles>

$\operatorname{Ar}=$<smiles>CC(C)(C)c1ccc(N(c2ccccc2)c2ccccc2)cc1</smiles>

Scheme 2. Synthesis of TI116 sensitizer.

The optical properties of these dyes were investigated using UV/Vis absorption spectroscopy and shown in Figure 2. The absorption spectrum of the parent dye TI111 features $\lambda_{\max }$ of $469 \mathrm{~nm}$ [molar absorption coefficient $(\varepsilon)=3.77 \times 10^{4} \mathrm{M}^{-1} \mathrm{~cm}^{-1}$ ] which is attributed to the delocalized $\pi-\pi^{*}$ 
transition (Figure 2a). The halogen substituents played an important role in the absorption properties of the corresponding dyes. The $\lambda_{\max }$ of the dyes TI112 $\left(480 \mathrm{~nm}, \varepsilon=3.05 \times 10^{4} \mathrm{M}^{-1} \mathrm{~cm}^{-1}\right)$ with F substituent was found to red-shift $11 \mathrm{~nm}$. However, decrease in molar extinction coefficient was observed when compared to the non-substituted dye TI111. Nevertheless, dye TI114 $\left(\lambda_{\max }=483 \mathrm{~nm}\right.$, $\varepsilon=3.88 \times 10^{4} \mathrm{M}^{-1} \mathrm{~cm}^{-1}$ ) with Br substituent exhibited the highest $\lambda_{\text {max }}$ and $\varepsilon$. Surprisingly, dye TI115 $\left(\lambda_{\max }=483 \mathrm{~nm}, \varepsilon=3.47 \times 10^{4} \mathrm{M}^{-1} \mathrm{~cm}^{-1}\right)$ showed lower $\varepsilon$ in which $\mathrm{Br}$ is replaced with I substituent. These results revealed that, in comparison to other halogenated dyes, the Br substitution in the oxindole dye was more effective towards improving the light-harvesting capacity. It is interesting to note that, changing the position of substituent with respect to the anchoring group in TI116 showed a steep decrease in the absorption intensity, compared to the TI114 dye which might have resonance interaction of the substituent with the anchoring group. Mostly, organic dyes featured blue-shifts in the absorption bands when attached onto the $\mathrm{TiO}_{2}$ surface. Such a phenomenon was attributed to deprotonation of the carboxylic acid or the formation of aggregation of the sensitizers [61-66]. The UV/Vis absorption spectra of oxindole dyes anchored onto $\mathrm{TiO}_{2}$ films (Figure $2 \mathrm{~b}$ ) were broadened. Compared to the solutions, sensitizers TI112-TI115 on films exhibited stronger adsorption than the dye TI111.
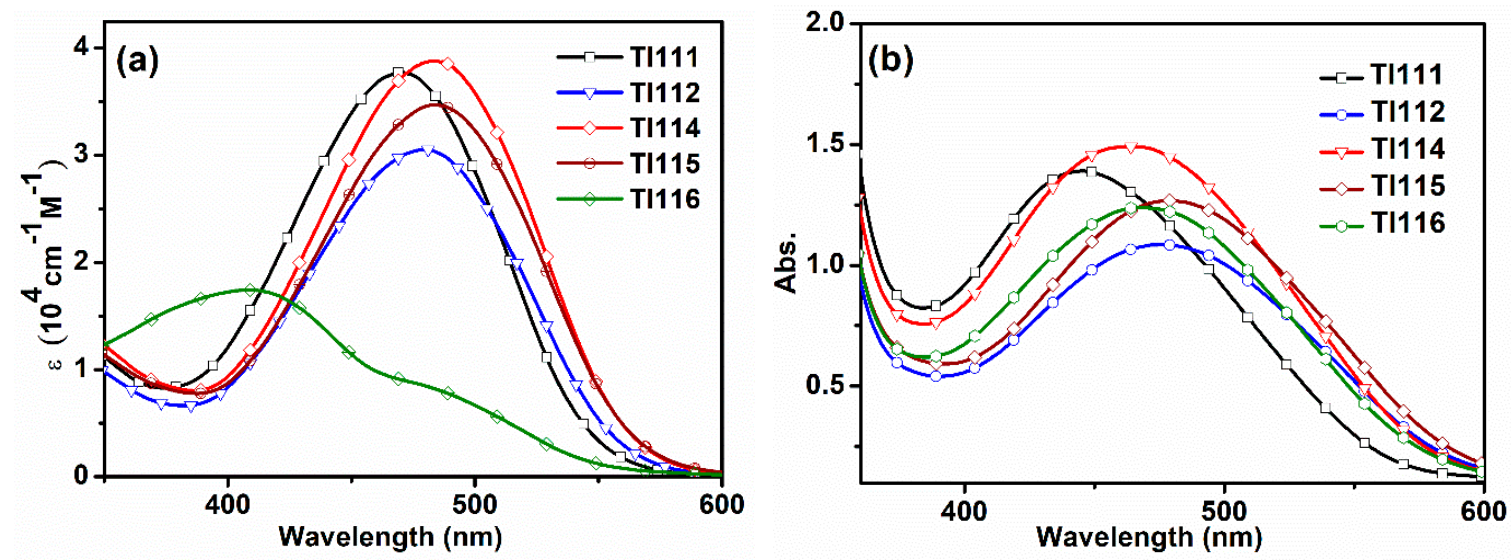

Figure 2. (a) Absorption spectra of TI111-TI116 in $\mathrm{CH}_{2} \mathrm{Cl}_{2}$. (b) Absorption spectra for transparent $\mathrm{TiO}_{2}$ films (thickness: $5 \mu \mathrm{m}$ ) coated with $8.0 \times 10^{-5} \mathrm{M}$ solutions of TI111-TI116.

The HOMO and LUMO energy levels of the sensitizer play an important role in affecting the dye-regeneration and electron-transfer processes in DSSCs. Table 1 reveals that the HOMO levels of these dyes are lower than that of $\mathrm{I}^{-} / \mathrm{I}^{3-}$ redox potential, assuring regeneration of the oxidized dyes by the redox couple in the electrolyte. The LUMO levels of the sensitizers TI111-TI116 were adequate for efficient electron injection and the halogen substitutions do not alter the energy levels of these dyes. To gain further insight into the frontier orbital profiles, the locations of the HOMOs and LUMOs of oxindole dyes were calculated using a semiempirical computation method. The molecular orbital calculations showed that the HOMO orbital of each dye is localized to the electron-rich TPA moiety (Figure $3 a$ and Figure S2 in the Supporting Information). Interestingly, in each oxindole dye, the LUMO level is confined to the amide portion of the molecule and does not extend to the non-conjugated anchoring carboxylate moiety. These calculations indicate that each oxindole dye is poised for effective electron injection through the amide group rather than the anchoring carboxylate moiety. To confirm this inference and explore the electron injection mechanism in the oxindoles, FTIR spectra of TI114 powder and the dye adsorbed on $\mathrm{TiO}_{2}$ were measured. The characteristic band for the amide carbonyl group of the oxindole dye TI114 powder was observed at $1678 \mathrm{~cm}^{-1}$ (Figure $3 \mathrm{~b}$ ). When the dye was adsorbed on the $\mathrm{TiO}_{2}$ surface, the peak for $\mathrm{C}=\mathrm{O}$ stretching disappeared which clearly verified the chelation of the amide carbonyl group of the oxindole dye to the $\mathrm{TiO}_{2}$ surface. With such chelations, oxindole sensitizers are expected to improve photo-induced electron injection yields. 
Table 1. Electrochemical properties for TI111-TI116 dyes.

\begin{tabular}{ccccc}
\hline Dye & $\lambda_{\text {abs }} / \mathbf{n m}\left(\varepsilon / \mathbf{L ~ m o l}^{-\mathbf{1}} \mathbf{~ c m}^{-\mathbf{1}}\right)$ & $E_{\text {HOMO }}[\mathbf{a}](\mathbf{e V})$ & $E_{\text {LUMO }}[\mathbf{b}](\mathbf{e V})$ & $E_{0-0}[\mathbf{b}](\mathbf{e V})$ \\
\hline TI111 & $469(3.7737)$ & 5.11 & 3.02 & 2.09 \\
TI112 & $480(3.0562)$ & 5.11 & 3.05 & 2.06 \\
TI114 & $483(3.8825)$ & 5.11 & 3.08 & 2.03 \\
TI115 & $483(3.4712)$ & 5.12 & 3.09 & 2.03 \\
TI116 & $410(1.7437)$ & 5.11 & 3.06 & 2.05 \\
\hline
\end{tabular}

[a] $E_{\mathrm{HOMO}}=E_{\mathrm{Ox}}-E_{\mathrm{Fc} / \mathrm{Fc}}{ }^{+}+4.8 \mathrm{eV}$. [b] $E_{\mathrm{LUMO}}=E_{\mathrm{HOMO}}-E_{0-0}$. The band gap, $E_{0-0}$, was estimated from the onset of absorption spectrum measured in $\mathrm{CH}_{2} \mathrm{Cl}_{2}$.
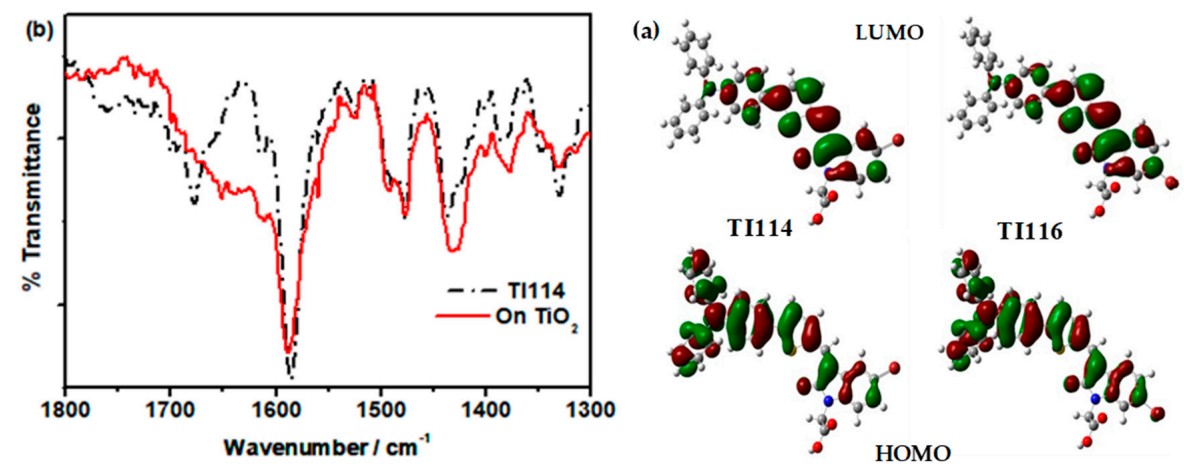

Figure 3. (a) Frontier molecular orbital profiles of TI114 and TI116 at the B3LYP/6-31g (d,p) level.

(b) FTIR spectra of the TI114 dye powder and dye adsorbed on film.

Table 2 summarizes the cell performance of the DSSCs anchored with oxindole dyes: short-circuit photocurrent densities $\left(J_{\mathrm{sc}}\right)$, open-circuit voltages $\left(V_{\mathrm{oc}}\right)$, fill factors $(\mathrm{FFs})$, and solar-to-electricity conversion efficiencies $(\eta)$. Figure 4 presents their corresponding photocurrent density-voltage $(I-V)$ curves, incident photo-to-current efficiency (IPCE) spectra and electrochemical impedance spectroscopy (EIS). The parent dye TI111 exhibited $J_{\mathrm{sc}}=10.03 \mathrm{~mA} \mathrm{~cm}^{-2}, V_{\mathrm{oc}}=680 \mathrm{mV}$, and FF $=0.699$, corresponding to an overall $\eta=4.76 \%$ (Table 2). Furthermore, incorporating the halogen substitutions in the oxindole dyes enhanced the device conversion efficiencies. The DSSC based on the F-substituted TI112 sensitizer achieved $J_{\mathrm{SC}}=11.32 \mathrm{~mA} \mathrm{~cm}^{-2}, V_{\mathrm{oc}}=690 \mathrm{mV}$, and $\mathrm{FF}=0.695$, corresponding to an overall $\eta=5.43 \%$, which was approximately $14 \%$ higher than that of the non-substituted oxindole sensitizer TI111. The enhanced $\eta$ was due to its increase in the $J_{\mathrm{sc}}$ which could be attributed to the electronic coupling of $\mathrm{F}$ with the anchoring group [58]. Replacing the F with other halogen substituents in the oxindoles showed further enhancement in the DSSC performance. Among all the halogen substituted sensitizers reported in this study, the $\mathrm{Br}$ incorporated sensitizer TI114 exhibited the highest photovoltaic parameters $\left(J_{\mathrm{sc}}=12.46 \mathrm{~mA} \mathrm{~cm}{ }^{-2}, V_{\mathrm{oc}}=720 \mathrm{mV}\right.$, and FF $\left.=0.708\right)$ with an overall conversion efficiency $(\eta)$ of $6.35 \%$. The improved photocurrent of the TI114 sensitizer suggests that compared to F substitution, the Br-substituted dye can exhibit better cell performance. Also, compared to the dye with the traditional cyanoacrylic acid acceptor bearing the same TPA donor- $\pi$-bridge moiety [67], the sensitizer with the Br-substituted oxindole acceptor seems to be more impressive. Surprisingly, changing the position of the substituent with respect to the anchoring group exhibited negative effect on the solar cell performance. The TI116 anchored DSSC showed lower current density $\left(J_{\mathrm{sc}}=9.66 \mathrm{~mA} \mathrm{~cm}^{-2}, V_{\mathrm{oc}}=630 \mathrm{mV}\right.$, and $\left.\mathrm{FF}=0.690\right)$, that is corresponding to an overall $\eta=4.21 \%$, which may be due to the absence of electronic coupling of substitution with the anchoring group. In order to gain more insight into the electron transport of oxindole dyes, the electrochemical impedance of the cells was measured under illumination and is shown in Figure 4c. The fitted EIS data, the charge transfer resistance related to the recombination of electrons at the interface $\left(R_{k}\right)$, the electron transport resistance in the photoanode $\left(\mathrm{R}_{\mathrm{W}}\right)$, the effective rate constant for recombination $\left(k_{\text {eff }}\right)$, the electron lifetime in the photoanode $(\tau)$, the effective electron diffusion coefficient $\left(D_{\text {eff }}\right)$, and the electron diffusion length $\left(\mathrm{L}_{n}\right)$ are compiled in Table S4 in SI. The radii of the semicircles in the EIS spectra of the DSSCs based on oxindole dyes, according to the Nyquist plot, is in the order 
of TI116 $>$ TI111 $>$ TI112 $>$ TI115 $>$ TI114. These results indicate that the charge transport is in the order of TI114 $>$ TI115 $>$ TI112 $>$ TI111 $>$ TI116, which agrees with the overall device performances. Also, the life time $(\boldsymbol{\tau})$ values shown in Table S4 indicates that the capacity to suppress the back reaction of the electron with the $\mathrm{I}_{3}{ }^{-}$in the electrolyte are affected by the different halogen substituent on the oxindole moiety. The measured $\tau$ is in the order of TI114 $=$ TI112 $>$ TI115 $=$ TI111 $>$ TI116 and is consistent with those of $V_{\mathrm{oc}}$ determined experimentally (see Table 2). Among all the sensitizers studied here, the dye TI114 showed the highest charge transport, lowest electron transport resistance and better electron lifetime which have led enhancement in its $V_{\text {oc }}$ and efficiency. The IPCE of the device using the TI111 sensitizer exceeded 50\% in the spectral region ranging from 425 to $565 \mathrm{~nm}$ and reached a maximum of $52 \%$ (Figure $4 \mathrm{~b}$ ). Incorporating halogen substituents in the sensitizers displayed red-shifted ranges and increasing IPCE maxima. The dye TI114 with the Br substituent exhibited the maximum IPCE value of $60 \%$ at $585 \mathrm{~nm}$, which was the highest among the listed oxindole dyes. Similar to the I- $V$ curve (Figure $4 \mathrm{a}$ ), altering the position of the substituent also resulted in a lower IPCE value as well as a blue shift for dye TI116 (a maximum of $43 \%$ at $445 \mathrm{~nm}$ ). Based on these analyses and the previous report [58], we can estimate that the halogen substituent, particularly positioned para to the anchoring group, can have strong impact on the device performance of the sensitizer. We believe that the effectiveness of electron transport, the proper balance of Fermi level, and controlling affinity of the acceptors towards the semiconductor are the crucial factors affecting device performances of oxindole-based DSSCs. Such factors cannot be predicted intuitively and their physical origins need to be further addressed in future work.

Table 2. Photovoltaic parameters of devices incorporating TI111-TI116 sensitizers.

\begin{tabular}{ccccc}
\hline Sensitizer & $J_{S C}\left(\mathbf{m A ~ c m} \mathbf{~ c m}^{-2}\right)$ & $V_{\boldsymbol{O C}}(\mathbf{m V})$ & $\boldsymbol{F} \boldsymbol{F}$ & $\eta \mathbf{( \% )}$ \\
\hline TI111 & 10.03 & 680 & 0.669 & 4.76 \\
TI112 & 11.32 & 690 & 0.695 & 5.43 \\
TI114 & 12.46 & 720 & 0.708 & 6.35 \\
TI115 & 11.97 & 680 & 0.714 & 5.81 \\
TI116 & 9.66 & 630 & 0.692 & 4.21 \\
\hline
\end{tabular}
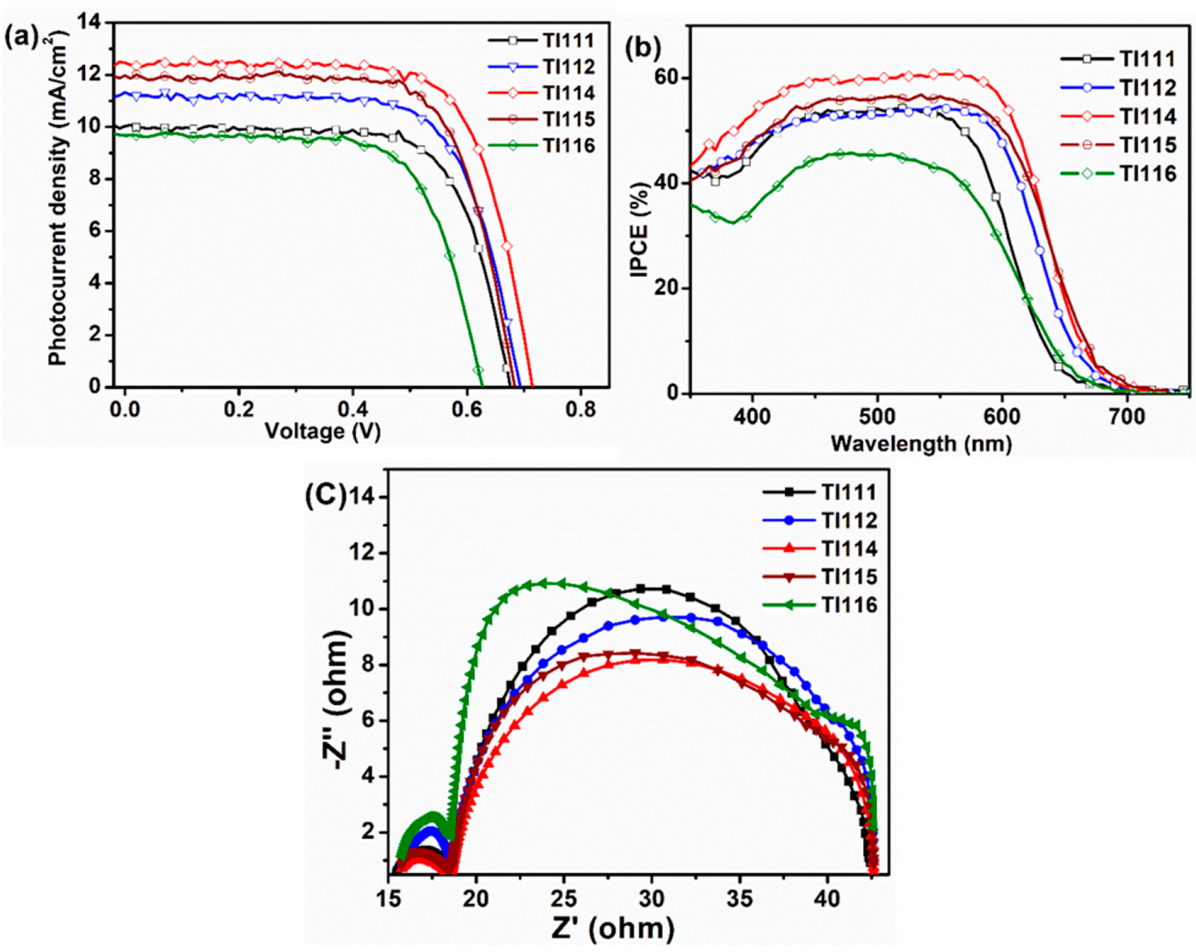

Figure 4. (a) Current versus potential plots and (b) Monochromatic IPCE spectra for sensitizers TI111-TI116. (c) EIS spectra measured under illumination of DSSCs based on TI111-TI116 dyes. 


\section{Materials and Methods}

General procedure for syntheses of compounds 3(a-d): In a $100 \mathrm{~mL}$ round bottom flask 5-[4-(diphenylamino) phenyl] thiophene-2-carbaldehyde (2) (12 mmol) was treated with the appropriate oxindole (1a-d) $(10 \mathrm{mmol})$ and piperidine $(1 \mathrm{mmol})$ in $20 \mathrm{~mL}$ of ethanol. After the reaction mixture was refluxed for $6 \mathrm{~h}$, it was cooled and the resulting precipitate was filtered, washed with cold ethanol, and dried to give the target compounds (70-90\% yield).

(Z)-3-((5-(4-(Diphenylamino)phenyl)thiophen-2-yl)methylene)indolin-2-one (3a; $3.8 \mathrm{~g}, 82.79 \%):{ }^{1} \mathrm{H}$ NMR $\left(300 \mathrm{MHz}, \mathrm{DMSO}-\mathrm{d}_{6}\right) \delta 10.64(\mathrm{~s}, 1 \mathrm{H}) ; 8.05(\mathrm{~s}, 1 \mathrm{H}) ; 7.89(\mathrm{~d}, J=4.2 \mathrm{~Hz}, 1 \mathrm{H}) ; 7.68(\mathrm{~d}, J=7.2 \mathrm{~Hz}, 1 \mathrm{H})$; $7.66(\mathrm{~d}, J=8.7 \mathrm{~Hz}, 2 \mathrm{H}) ; 7.52(\mathrm{~d}, J=3.9 \mathrm{~Hz}, 1 \mathrm{H}) ; 7.35(\mathrm{t}, J=7.8 \mathrm{~Hz}, 4 \mathrm{H}) ; 7.20(\mathrm{t}, J=7.2 \mathrm{~Hz}, 1 \mathrm{H}) ; 7.14-7.08$ $(\mathrm{m}, 6 \mathrm{H}) ; 7.02-6.97(\mathrm{~m}, 3 \mathrm{H}) ; 6.88(\mathrm{~d}, J=7.8 \mathrm{~Hz}, 1 \mathrm{H}) .{ }^{13} \mathrm{C}$ NMR $\left(75 \mathrm{MHz}, \mathrm{DMSO}-d_{6}\right) \delta 167.8 ; 150.9 ; 148.1$; $147.1 ; 140.8 ; 139.7 ; 136.4 ; 130.1 ; 128.7 ; 128.5 ; 127.5 ; 127.3 ; 125.1 ; 124.9 ; 124.2 ; 123.6 ; 122.9 ; 121.3 ; 121.3$; 119.7; 109.9. HRMS (FAB) $\left(m / z[M+H]^{+}\right)$calcd for $\mathrm{C}_{31} \mathrm{H}_{23} \mathrm{~N}_{2} \mathrm{OS}, 471.1526$; found 471.1513 .

(Z)-3-((5-(4-(Diphenylamino)phenyl)thiophen-2-yl)methylene)-5-fluoroindolin-2-one (3b; $3.4 \mathrm{~g}, 70.69 \%)$ : ${ }^{1} \mathrm{HNMR}\left(300 \mathrm{MHz}, \mathrm{DMSO}-d_{6}\right) \delta 10.63(\mathrm{~s}, 1 \mathrm{H}) ; 8.14(\mathrm{~s}, 1 \mathrm{H}) ; 7.89(\mathrm{~d}, J=3.9 \mathrm{~Hz}, 1 \mathrm{H}) ; 7.67(\mathrm{~d}, J=8.7 \mathrm{~Hz}, 2 \mathrm{H})$; $7.60(\mathrm{dd}, J=9,2.4 \mathrm{~Hz}, 1 \mathrm{H}) ; 7.55(\mathrm{~d}, J=3.9 \mathrm{~Hz}, 1 \mathrm{H}) ; 7.37(\mathrm{t}, J=7.6 \mathrm{~Hz}, 4 \mathrm{H}) ; 7.14(\mathrm{~d}, J=7.2 \mathrm{~Hz}, 2 \mathrm{H})$; $7.10(\mathrm{~d}, J=8.1 \mathrm{~Hz}, 5 \mathrm{H}) ; 7.01(\mathrm{~d}, J=8.4 \mathrm{~Hz}, 2 \mathrm{H}) ; 6.84(\mathrm{dd}, J=8.4,4.5 \mathrm{~Hz}, 1 \mathrm{H}) .{ }^{13} \mathrm{C} \mathrm{NMR}(75 \mathrm{MHz}$, DMSO- $\left.d_{6}\right) \delta 167.9 ; 159.8 ; 156.7 ; 151.7 ; 148.2 ; 147.0 ; 140.3 ; 137.0 ; 136.1 ; 130.1 ; 127.4 ; 127.3 ; 126.5$; $126.4 ; 125.1 ; 124.2 ; 123.7 ; 122.8 ; 120.8(\mathrm{~d}, J=7.5 \mathrm{~Hz}) ; 114.7(\mathrm{~d}, J=22.5 \mathrm{~Hz}) ; 110.4(\mathrm{~d}, J=7.5 \mathrm{~Hz})$; $107(\mathrm{~d}, \mathrm{~J}=24.7 \mathrm{~Hz})$. HRMS (FAB) $\left(\mathrm{m} / \mathrm{z}[\mathrm{M}]^{+}\right)$calcd for $\mathrm{C}_{31} \mathrm{H}_{21} \mathrm{FN}_{2} \mathrm{OS}, 488.1353$; found 488.1350 .

(Z)-5-bromo-3-((5-(4-(Diphenylamino)phenyl)thiophen-2-yl)methylene)indolin-2-one (3c; $4.2 \mathrm{~g}, 76.45 \%)$ : [54]: ${ }^{1} \mathrm{H}$ NMR (300 MHz, DMSO-d 6 ) $\delta 10.75(\mathrm{~s}, 1 \mathrm{H}) ; 8.22(\mathrm{~s}, 1 \mathrm{H}) ; 7.93(\mathrm{~s}, 1 \mathrm{H}) ; 7.89(\mathrm{~d}, J=3.6 \mathrm{~Hz}, 1 \mathrm{H})$; $7.69(\mathrm{~d}, J=8.7 \mathrm{~Hz}, 2 \mathrm{H}) ; 7.57(\mathrm{~d}, J=3.9 \mathrm{~Hz}, 1 \mathrm{H}) ; 7.40-7.35(\mathrm{~m}, 5 \mathrm{H}) ; 7.16-7.10(\mathrm{~m}, 6 \mathrm{H})$; $7.02(\mathrm{~d}, J=8.4 \mathrm{~Hz}, 2 \mathrm{H}) ; 6.83(\mathrm{~d}, J=8.4 \mathrm{~Hz}, 1 \mathrm{H}) .{ }^{13} \mathrm{C}$ NMR $\left(75 \mathrm{MHz}, \mathrm{DMSO}-d_{6}\right) \delta 167.4 ; 151.9 ; 148.3$; 147.0; 140.6; 139.7; 136.2; 130.7; 130.4; 130.2; 127.5; 127.3; 127.2; 125.1; 124.3; 123.8; 122.7; 122.4; 119.8; 113.3; 111.7. HRMS (FAB) $\left(m / z[M+H]^{+}\right)$calcd for $\mathrm{C}_{31} \mathrm{H}_{22} \mathrm{BrN}_{2} \mathrm{OS}$, 549.0631; found 549.0620.

(Z)-3-((5-(4-(Diphenylamino)phenyl)thiophen-2-yl)methylene)-5-iodoindolin-2-one (3d; 5.2 g, 86.95\%): ${ }^{1} \mathrm{H} \mathrm{NMR}\left(300 \mathrm{MHz}, \mathrm{DMSO}-d_{6}\right) \delta 10.71(\mathrm{~s}, 1 \mathrm{H}) ; 8.19(\mathrm{~s}, 1 \mathrm{H}) ; 8.07(\mathrm{~d}, J=1.5 \mathrm{~Hz}, 1 \mathrm{H}) ; 7.90(\mathrm{~d}, J=3.9 \mathrm{~Hz}, 1 \mathrm{H})$; $7.68(\mathrm{~d}, J=8.4 \mathrm{~Hz}, 2 \mathrm{H}) ; 7.56(\mathrm{~d}, J=3.9 \mathrm{~Hz}, 1 \mathrm{H}) ; 7.51(\mathrm{dd}, J=8.1,1.5 \mathrm{~Hz}, 1 \mathrm{H}) ; 7.37(\mathrm{t}, J=7.8 \mathrm{~Hz}, 4 \mathrm{H}) ; 7.15$ $(\mathrm{d}, J=7.5 \mathrm{~Hz}, 2 \mathrm{H}) ; 7.11(\mathrm{~d}, J=7.5 \mathrm{~Hz}, 4 \mathrm{H}) ; 7.02(\mathrm{~d}, J=8.4 \mathrm{~Hz}, 2 \mathrm{H}) ; 6.72(\mathrm{~d}, J=8.1 \mathrm{~Hz}, 1 \mathrm{H}) .{ }^{13} \mathrm{C} \mathrm{NMR}$ $(75 \mathrm{MHz}$, DMSO-d 6 ) $\delta 167.2 ; 151.8 ; 148.2 ; 147.0 ; 140.5 ; 140.1 ; 136.5 ; 136.2 ; 130.1 ; 127.9 ; 127.7 ; 127.4 ; 127.2$; $125.1 ; 124.2 ; 123.7 ; 122.8 ; 119.6 ; 112.2 ; 84.3$. HRMS (FAB) $\left(m / z[\mathrm{M}]^{+}\right)$calcd for $\mathrm{C}_{31} \mathrm{H}_{21} \mathrm{IN}_{2} \mathrm{OS}, 596.0414$; found 596.0413 .

General procedure for syntheses of compounds $4(\mathrm{a}-\mathrm{d})$ : To a solution of compound 3(a-d) $(10 \mathrm{mmol})$ in dimethylformamide $(50 \mathrm{~mL})$, potassium carbonate $(12 \mathrm{mmol})$ was added and stirred for $30 \mathrm{~min}$. Methyl bromoacetate $(12 \mathrm{mmol})$ and tetrabutylammonium bromide $(1 \mathrm{mmol})$ were then added and reaction mixture was continued stirring at room temperature for $48 \mathrm{~h}$. The reaction mixture was diluted by ethyl acetate $(30 \mathrm{~mL})$ and the salt formed was removed by filtration and washed with ethyl acetate $(6 \mathrm{~mL})$. The solution was then concentrated under reduced pressure. The resulting residue was purified by column chromatography $\left(\mathrm{SiO}_{2} ; \mathrm{CH}_{2} \mathrm{Cl}_{2}\right)$ to yield ester compounds (60-65\% yield).

Methyl (Z)-2-(3-((5-(4-(diphenylamino)phenyl)thiophen-2-yl)methylene)-2-oxoindolin-1-yl)acetate (4a; $2.81 \mathrm{~g}$, 64.15\%): ${ }^{1} \mathrm{H}$ NMR (300 MHz, DMSO-d $) \delta 8.17(\mathrm{~s}, 1 \mathrm{H}) ; 7.89(\mathrm{~d}, J=4.2 \mathrm{~Hz}, 1 \mathrm{H}) ; 7.75(\mathrm{~d}, J=6.9 \mathrm{~Hz}, 1 \mathrm{H})$; $7.67(\mathrm{~d}, J=8.7 \mathrm{~Hz}, 2 \mathrm{H}) ; 7.56(\mathrm{~d}, J=3.9 \mathrm{~Hz}, 1 \mathrm{H}) ; 7.35(\mathrm{t}, J=7.8 \mathrm{~Hz}, 4 \mathrm{H}) ; 7.25(\mathrm{t}, J=7.9 \mathrm{~Hz}, 1 \mathrm{H}) 7.14-7.09$ $(\mathrm{m}, 7 \mathrm{H}) ; 7.06(\mathrm{~d}, J=8.1 \mathrm{~Hz}, 1 \mathrm{H}) ; 7.01(\mathrm{~d}, J=5.4 \mathrm{~Hz}, 2 \mathrm{H}) ; 4.69(\mathrm{~s}, 2 \mathrm{H}) ; 3.69(\mathrm{~s}, 3 \mathrm{H}) .{ }^{13} \mathrm{C} \mathrm{NMR}(75 \mathrm{MHz}$, $\left.\mathrm{CDCl}_{3}\right) \delta 168.5 ; 166.3 ; 152.5 ; 148.3 ; 147.2 ; 140.4 ; 139.1 ; 136.2 ; 129.4 ; 129.0 ; 128.0 ; 127.4 ; 127.1 ; 124.9$; $124.1 ; 123.5 ; 122.9 ; 122.5 ; 122.1 ; 119.2 ; 118.7 ; 107.9 ; 52.5 ; 41.0$. HRMS (FAB) $\left(m / z[M+H]^{+}\right)$calcd for $\mathrm{C}_{34} \mathrm{H}_{27} \mathrm{~N}_{2} \mathrm{O}_{3} \mathrm{~S}, 543.1737$; found 543.1732. 
Methyl (Z)-2-(3-((5-(4-(diphenylamino)phenyl)thiophen-2-yl)methylene)-5-fluoro-2-oxoindolin-1-yl)acetate (4b; $2.39 \mathrm{~g}, 61.43 \%):{ }^{1} \mathrm{H}$ NMR (300 MHz, DMSO- $\left.d_{6}\right) \delta 8.29(\mathrm{~s}, 1 \mathrm{H}) ; 7.91(\mathrm{~d}, J=4.2 \mathrm{~Hz}, 1 \mathrm{H})$; $7.71(\mathrm{~d}, J=8.7 \mathrm{~Hz}, 2 \mathrm{H}) ; 7.61(\mathrm{~d}, J=3.9 \mathrm{~Hz}, 1 \mathrm{H}) ; 7.38(\mathrm{t}, J=7.6 \mathrm{~Hz}, 4 \mathrm{H}) ; 7.15-7.10(\mathrm{~m}, 9 \mathrm{H})$; $7.10(\mathrm{~d}, J=3.9 \mathrm{~Hz}, 2 \mathrm{H}) ; 4.72(\mathrm{~s}, 2 \mathrm{H}) ; 3.72(\mathrm{~s}, 3 \mathrm{H}) .{ }^{13} \mathrm{C} \mathrm{NMR}\left(75 \mathrm{MHz}, \mathrm{CDCl}_{3}\right) \delta$ 168.4; 166.2; 161.2; $159.8 ; 153.4 ; 148.4 ; 147.1 ; 139.8 ; 136.3 ; 135.8 ; 130.1 ; 129.4 ; 127.1 ; 124.9 ; 123.6 ; 122.7 ; 122.6 ; 118.6 ; 114.1$ $(\mathrm{d}, J=22.5 \mathrm{~Hz}) ; 108.3(\mathrm{~d}, J=7.5 \mathrm{~Hz}) ; 106.1(\mathrm{~d}, J=22.5 \mathrm{~Hz}) ; 52.5 ; 41.1$. HRMS (FAB) $\left(m / z[\mathrm{M}]^{+}\right)$calcd for $\mathrm{C}_{34} \mathrm{H}_{25} \mathrm{FN}_{2} \mathrm{O}_{3} \mathrm{~S}$, 560.1564; found 560.1568 .

Methyl (Z)-2-(5-bromo-3-((5-(4-(diphenylamino)phenyl)thiophen-2-yl)methylene)-2-oxoindolin-1-yl)acetate $(4 \mathrm{c} ; 3.02 \mathrm{~g}, 63.84 \%){ }^{1} \mathrm{H}$ NMR $\left(300 \mathrm{MHz}, \mathrm{DMSO}-d_{6}\right) \delta 8.35(\mathrm{~s}, 1 \mathrm{H}) ; 8.03(\mathrm{~s}, 1 \mathrm{H}) ; 7.91(\mathrm{~d}, J=3.6 \mathrm{~Hz}, 1 \mathrm{H})$; $7.70(\mathrm{~d}, J=8.4 \mathrm{~Hz}, 2 \mathrm{H}) ; 7.60(\mathrm{~d}, J=3.9 \mathrm{~Hz}, 1 \mathrm{H}) 7.44(\mathrm{~d}, J=8.4 \mathrm{~Hz}, 1 \mathrm{H}) ; 7.38(\mathrm{t}, J=7.6 \mathrm{~Hz}, 4 \mathrm{H}) ; 7.17-7.10$ $(\mathrm{m}, 6 \mathrm{H}) ; 7.06(\mathrm{~d}, J=8.4 \mathrm{~Hz}, 1 \mathrm{H}) ; 7.01(\mathrm{~d}, J=8.4 \mathrm{~Hz}, 2 \mathrm{H}) ; 4.72(\mathrm{~s}, 2 \mathrm{H}) ; 3.71(\mathrm{~s}, 3 \mathrm{H}) .{ }^{13} \mathrm{C} \mathrm{NMR}(75 \mathrm{MHz}$, $\left.\mathrm{CDCl}_{3}\right) \delta 168.3 ; 165.8 ; 153.5 ; 148.4 ; 140.1 ; 139.0 ; 135.8 ; 130.2 ; 130.2 ; 129.4 ; 127.1 ; 126.1 ; 125.0 ; 123.6$; 122.7; 121.6; 117.6; 114.8; 109.3. HRMS (FAB) $\left(m / z[\mathrm{M}+\mathrm{H}]^{+}\right)$calcd for $\mathrm{C}_{34} \mathrm{H}_{26} \mathrm{BrN}_{2} \mathrm{O}_{3} \mathrm{~S}, 621.0842$; found 621.0841 .

Methyl (Z)-2-(3-((5-(4-(diphenylamino)phenyl)thiophen-2-yl)methylene)-5-iodo-2-oxoindolin-1-yl)acetate $(4 \mathrm{~d} ; 4.63 \mathrm{~g}, 64.84 \%){ }^{1} \mathrm{H}$ NMR $\left(300 \mathrm{MHz}, \mathrm{DMSO}-d_{6}\right) \delta 8.28(\mathrm{~s}, 1 \mathrm{H}) ; 8.13(\mathrm{~s}, 1 \mathrm{H}) ; 7.89(\mathrm{~d}, J=3.9 \mathrm{~Hz}, 1 \mathrm{H})$; $7.66(\mathrm{~d}, J=8.7 \mathrm{~Hz}, 2 \mathrm{H}) ; 7.57(\mathrm{~d}, J=8.4 \mathrm{~Hz}, 1 \mathrm{H}) ; 7.55(\mathrm{~d}, J=3.9 \mathrm{~Hz}, 1 \mathrm{H}) ; 7.36(\mathrm{t}, J=7.8 \mathrm{~Hz}, 4 \mathrm{H})$; 7.15-7.08 (m, 6H); $6.99(\mathrm{~d}, J=8.7 \mathrm{~Hz}, 2 \mathrm{H}) ; 6.92(\mathrm{~d}, J=8.4 \mathrm{~Hz}, 1 \mathrm{H}) ; 4.69(\mathrm{~s}, 2 \mathrm{H}) ; 3.71(\mathrm{~s}, 3 \mathrm{H}) .{ }^{13} \mathrm{C} \mathrm{NMR}$ (75 MHz, DMSO- $d_{6}$ ) $\delta 169.0 ; 165.5 ; 152.5 ; 148.4 ; 147.0 ; 141.2 ; 140.3 ; 136.4 ; 136.1 ; 131.3 ; 130.1 ; 127.8 ; 127.4$; $127.0 ; 126.6 ; 125.2 ; 124.3 ; 123.8 ; 122.6 ; 117.6 ; 111.5 ; 85.4 ; 52.7 ; 41.2$. HRMS (FAB) $\left(m / z[M]^{+}\right)$calcd for $\mathrm{C}_{34} \mathrm{H}_{25} \mathrm{IN}_{2} \mathrm{O}_{3} \mathrm{~S}$, 668.0625; found 668.0622.

General procedure for syntheses of sensitizers TI111-TI115: Compound 4(a-d) (9 mmol) was dissolved in THF $(6 \mathrm{~mL})$ and $0.5 \mathrm{M} \mathrm{NaOH}_{(\mathrm{aq} .)}(18 \mathrm{mmol})$ was added to the solution, which was then stirred at room temperature for $6 \mathrm{~h}$. After the hydrolysis was completed, the solvent was evaporated. Ethanol $(5 \mathrm{~mL})$ was added and the resulting precipitate was filtered, washed with cold ethanol $(0.5 \mathrm{~mL})$, and dried. The precipitate were then dissolved in water $(10 \mathrm{~mL})$ and $0.5 \mathrm{M} \mathrm{HCl}_{(\mathrm{aq} .)}$ was added to precipitate the product. The solid was filtered, washed with water $(3 \times 6 \mathrm{~mL})$ and dried under vacuum to afford target sensitizers (80-90\% yield).

Dye TI111 (2.35 g, 86.08\%): ${ }^{1} \mathrm{H}$ NMR (500 MHz, DMSO- $\left.d_{6}\right) \delta 8.32(\mathrm{~d}, J=7.6 \mathrm{~Hz}, 1 \mathrm{H}) ; 7.85(\mathrm{~s}, 2 \mathrm{H}) ; 7.73$ $(\mathrm{d}, J=8.6 \mathrm{~Hz}, 2 \mathrm{H}) ; 7.60(\mathrm{~d}, J=4 \mathrm{~Hz}, 1 \mathrm{H}) ; 7.37-7.32(\mathrm{~m}, 5 \mathrm{H}) ; 7.14-7.05(\mathrm{~m}, 8 \mathrm{H}) ; 6.99(\mathrm{~d}, J=8.5 \mathrm{~Hz}, 2 \mathrm{H})$; 4.54 (s, 2H). ${ }^{13} \mathrm{C}$ NMR (125 MHz, DMSO-d 6 ) $\delta 169.9 ; 168.6 ; 150.0 ; 148.4 ; 146.9 ; 143.1 ; 139.4 ; 135.5 ; 130.1$; $129.8 ; 128.5 ; 127.6 ; 126.5 ; 125.2 ; 124.4 ; 124.3 ; 123.6 ; 122.6 ; 122.4 ; 121.2 ; 120.6 ; 109.4 ; 41.6$. HRMS (FAB) $\left(\mathrm{m} / z[\mathrm{M}+\mathrm{H}]^{+}\right)$calcd for $\mathrm{C}_{33} \mathrm{H}_{25} \mathrm{~N}_{2} \mathrm{O}_{3} \mathrm{~S}, 529.1580$; found 529.1570.

Dye TI112 (2.38 g, 80.13\%): ${ }^{1} \mathrm{H}$ NMR (300 MHz, DMSO- $\left.d_{6}\right) \delta 8.24(\mathrm{~s}, 1 \mathrm{H}) ; 7.91(\mathrm{~d}, J=3.9 \mathrm{~Hz}, 1 \mathrm{H})$; $7.71(\mathrm{~d}, J=8.7 \mathrm{~Hz}, 2 \mathrm{H}) ; 7.66(\mathrm{~d}, J=2.1 \mathrm{~Hz}, 1 \mathrm{H}) ; 7.59(\mathrm{~d}, J=3.9 \mathrm{~Hz}, 1 \mathrm{H}) ; 7.38(\mathrm{t}, J=7.6 \mathrm{~Hz}, 4 \mathrm{H}) ; 7.17-7.11$ $(\mathrm{m}, 8 \mathrm{H}) ; 7.02(\mathrm{~d}, J=8.7 \mathrm{~Hz}, 2 \mathrm{H}) ; 4.52(\mathrm{~s}, 2 \mathrm{H}) .{ }^{13} \mathrm{C}$ NMR $(125 \mathrm{MHz}$, DMSO-d 6 ) $\delta 169.8 ; 168.4 ; 159.1 ; 157.3$; $150.8 ; 148.5 ; 146.9 ; 140.2 ; 139.4 ; 135.0 ; 130.1 ; 127.6 ; 126.2 ; 125.2 ; 124.6 ; 124.4 ; 122.4 ; 121.5 ;(\mathrm{d}, J=8.8 \mathrm{~Hz})$; $120.5 ; 115.9(\mathrm{~d}, J=40 \mathrm{~Hz}) ; 110.5(\mathrm{~d}, J=41.2 \mathrm{~Hz}) ; 41.7$. HRMS (FAB) $\left(\mathrm{m} / z[\mathrm{M}]^{+}\right)$calcd for $\mathrm{C}_{33} \mathrm{H}_{23} \mathrm{FN}_{2} \mathrm{O}_{3} \mathrm{~S}$, 546.1408; found 546.1405 .

Dye TI114 (2.63 g, 89.15\%): ${ }^{1} \mathrm{H}$ NMR (500 MHz, DMSO- $\left.d_{6}\right) \delta 8.29$ (s, 1H); $7.87(\mathrm{~s}, 2 \mathrm{H})$; $7.64(\mathrm{~d}, J=8.2 \mathrm{~Hz}, 2 \mathrm{H}) ; 7.59(\mathrm{~s}, 1 \mathrm{H}) ; 7.49(\mathrm{~d}, J=8 \mathrm{~Hz}, 1 \mathrm{H}) ; 7.34(\mathrm{t}, J=7.3 \mathrm{~Hz}, 4 \mathrm{H}) ; 7.13-7.04(\mathrm{~m}, 7 \mathrm{H})$; $6.97(\mathrm{~d}, J=8.2 \mathrm{~Hz}, 2 \mathrm{H}) ; 4.53(\mathrm{~s}, 2 \mathrm{H}) .{ }^{13} \mathrm{C}$ NMR $\left(125 \mathrm{MHz}, \mathrm{DMSO}-d_{6}\right) \delta 169.7 ; 168.1 ; 150.7 ; 148.7 ; 146.9$; $142.2 ; 140.3 ; 135.0 ; 132.0 ; 130.2 ; 127.6 ; 126.1 ; 125.3 ; 124.8 ; 124.4 ; 122.7 ; 122.4 ; 120.0 ; 113.9 ; 111.4 ; 41.7$. HRMS (FAB) $\left(\mathrm{m} / \mathrm{z}[\mathrm{M}]^{+}\right)$calcd for $\mathrm{C}_{33} \mathrm{H}_{23} \mathrm{BrN}_{2} \mathrm{O}_{3} \mathrm{~S}, 606.0613$; found 606.0603.

Dye TI115 (3.23 g, 87.53\%): ${ }^{1} \mathrm{H}$ NMR (500 MHz, DMSO- $\left.d_{6}\right) \delta 8.28$ (s, 1H); $8.11(\mathrm{~s}, 1 \mathrm{H})$; $7.88(\mathrm{~d}, J=3.7 \mathrm{~Hz}, 1 \mathrm{H}) ; 7.68(\mathrm{~d}, J=8.5 \mathrm{~Hz}, 2 \mathrm{H}) ; 7.56(\mathrm{~d}, J=3.7 \mathrm{~Hz}, 1 \mathrm{H}) ; 7.34(\mathrm{~d}, J=7.3 \mathrm{~Hz}, 4 \mathrm{H})$; 7.11-7.08 (m, 7H); $6.98(\mathrm{~d}, J=3.7 \mathrm{~Hz}, 2 \mathrm{H}) ; 6.89(\mathrm{~d}, J=8.2 \mathrm{~Hz}, 1 \mathrm{H}) ; 4.53(\mathrm{~s}, 2 \mathrm{H}) .{ }^{13} \mathrm{C}$ NMR $(125 \mathrm{MHz}$, DMSO- $\left.d_{6}\right) \delta 169.9 ; 165.5 ; 152.3 ; 148.3 ; 147.0 ; 141.0 ; 140.7 ; 136.3 ; 136.1 ; 131.0 ; 130.1 ; 127.7 ; 127.4 ; 127.1$; 
$126.5 ; 125.3 ; 125.2 ; 124.3 ; 123.8 ; 122.6 ; 117.9 ; 111.5 ; 85.2 ; 41.5$. HRMS (FAB) $\left(m / z[M]^{+}\right)$calcd for $\mathrm{C}_{33} \mathrm{H}_{23} \mathrm{IN}_{2} \mathrm{O}_{3} \mathrm{~S}$, 654.0469; found 654.0467.

(Z)-6-bromo-3-((5-(4-(Diphenylamino)phenyl)thiophen-2-yl)methylene)indolin-2-one (6): 6-Bromo-1H-indole2,3-dione (5) (2 g, $8.84 \mathrm{mmol}), 5$-[4-(diphenylamino)phenyl]thiophene-2-carbaldehyde (2) (6.29 $\mathrm{g}$, $17.69 \mathrm{mmol})$, and $\mathrm{PPh}_{3}(4.64 \mathrm{~g}, 17.69 \mathrm{mmol})$ were combined and dissolved in $20 \mathrm{~mL}$ of toluene in a microwave reaction vessel containing a magnetic stir bar. The reaction vessel was irradiated in the Synthos 3000 microwave oven at $300 \mathrm{~W}$ for $4 \mathrm{~h}$ (up to $110^{\circ} \mathrm{C}$ ). After the removal of solvent, the crude product was purified by column chromatography $\left(\mathrm{SiO}_{2} ; \mathrm{CH}_{2} \mathrm{Cl}_{2}\right)$ to afford compound 6 (2.88, 60\% yield). ${ }^{1} \mathrm{H}$ NMR (300 MHz, DMSO- $\left.d_{6}\right) \delta 10.76(\mathrm{~s}, 1 \mathrm{H}) ; 8.13(\mathrm{~s}, 1 \mathrm{H}) ; 7.91(\mathrm{~d}, J=3.6 \mathrm{~Hz}, 1 \mathrm{H})$; $7.68(\mathrm{~d}, J=7.8 \mathrm{~Hz}, 1 \mathrm{H}) ; 7.64(\mathrm{~d}, J=8.4 \mathrm{~Hz}, 2 \mathrm{H}) ; 7.55(\mathrm{~d}, J=3.9 \mathrm{~Hz}, 1 \mathrm{H}) ; 7.37(\mathrm{t}, J=7.5 \mathrm{~Hz}, 4 \mathrm{H})$; $7.19(\mathrm{~d}, J=8.1,1 \mathrm{H}) ; 7.16-7.09(\mathrm{~m}, 6 \mathrm{H}) ; 7.03-7.00(\mathrm{~m}, 3 \mathrm{H}) .{ }^{13} \mathrm{C}$ NMR $\left(75 \mathrm{MHz}, \mathrm{DMSO}-d_{6}\right) \delta 167.5 ; 151.6$; $148.2 ; 147.0 ; 141.9 ; 140.4 ; 136.2 ; 130.2 ; 129.7 ; 127.4 ; 127.3 ; 125.1 ; 124.3 ; 24.0 ; 123.8 ; 122.8 ; 121.4 ; 120.9$; 120.0; 112.5. HRMS (FAB) $\left(\mathrm{m} / z[\mathrm{M}+\mathrm{H}]^{+}\right)$calcd for $\mathrm{C}_{31} \mathrm{H}_{22} \mathrm{ON}_{2} \mathrm{BrS}$, 549.0631; found 549.0632.

Methyl (Z)-2-(6-bromo-3-((5-(4-(diphenylamino)phenyl)thiophen-2-yl)methylene)-2-oxoindolin-1-yl)acetate (7): Compound 7 was prepared from compound 6 using a method similar to that described for the synthesis of compound 4 to get $1.86 \mathrm{~g}(57 \%)$ final ester. ${ }^{1} \mathrm{H}$ NMR $\left(300 \mathrm{MHz}, \mathrm{DMSO}-d_{6}\right) \delta 8.23(\mathrm{~s}, 1 \mathrm{H})$; $7.90(\mathrm{~d}, J=3.6 \mathrm{~Hz}, 1 \mathrm{H}) ; 7.69(\mathrm{~d}, J=7.2 \mathrm{~Hz}, 1 \mathrm{H}) ; 7.67(\mathrm{~d}, J=7.8 \mathrm{~Hz}, 2 \mathrm{H}) ; 7.56(\mathrm{~d}, J=3.9 \mathrm{~Hz}, 1 \mathrm{H}) ; 7.39-7.32$ $(\mathrm{m}, 5 \mathrm{H}) ; 7.27(\mathrm{~d}, J=8.1 \mathrm{~Hz}, 1 \mathrm{H}) ; 7.14-7.07(\mathrm{~m}, 6 \mathrm{H}) ; 6.98(\mathrm{~d}, J=7.8 \mathrm{~Hz}, 2 \mathrm{H}) ; 4.71(\mathrm{~s}, 2 \mathrm{H}) ; 3.69(\mathrm{~s}, 3 \mathrm{H})$. ${ }^{13} \mathrm{C}$ NMR $\left(75 \mathrm{MHz}, \mathrm{CDCl}_{3}\right) \delta 168.1 ; 166.0 ; 153.2 ; 148.4 ; 147.1 ; 141.2 ; 139.5 ; 136.0 ; 129.5 ; 129.3 ; 127.2 ;$ $127.0 ; 124.9 ; 123.5 ; 123.1 ; 122.7 ; 122.6 ; 121.3 ; 119.6 ; 118.0 ; 111.2 ; 52.6 ; 41.0$. HRMS (FAB) $\left(m / z[\mathrm{M}]^{+}\right)$calcd for $\mathrm{C}_{34} \mathrm{H}_{25} \mathrm{BrN}_{2} \mathrm{O}_{3} \mathrm{~S}, 620.0769$; found 620.0770 .

Synthesis of sensitizer TI116: Dye TI116 was prepared from compound 7 using a method similar to that described for the synthesis of sensitizer TI111 to get $1.03 \mathrm{~g} \mathrm{(56 \% )}{ }^{1} \mathrm{H}$ NMR (500 MHz, DMSO- $d_{6}$ ) $\delta 8.22(\mathrm{~d}, J=8.1 \mathrm{~Hz}, 1 \mathrm{H}) ; 7.89(\mathrm{~d}, J=4.2 \mathrm{~Hz}, 2 \mathrm{H}) ; 7.73(\mathrm{~d}, J=8.7 \mathrm{~Hz}, 2 \mathrm{H}) ; 7.61(\mathrm{~d}, J=3.9 \mathrm{~Hz}, 1 \mathrm{H})$; $7.40-7.28(\mathrm{~m}, 6 \mathrm{H}) ; 7.14-7.08(\mathrm{~m}, 6 \mathrm{H}) ; 6.98(\mathrm{~d}, J=8.4 \mathrm{~Hz}, 2 \mathrm{H}) ; 4.56(\mathrm{~s}, 2 \mathrm{H}) .{ }^{13} \mathrm{C}$ NMR $\left(125 \mathrm{MHz}, \mathrm{DMSO}-d_{6}\right)$ $\delta 169.8 ; 168.5 ; 150.6 ; 148.5 ; 146.9 ; 144.5 ; 140.0 ; 135.3 ; 130.1 ; 129.3 ; 127.6 ; 126.4 ; 125.2 ; 124.9 ; 124.6 ; 124.4$; 122.6; 122.4; 119.9; 119.8; 112.6; 41.8. HRMS (FAB) $\left(m / z[M]^{+}\right)$calcd for $\mathrm{C}_{33} \mathrm{H}_{23} \mathrm{BrN}_{2} \mathrm{O}_{3} \mathrm{~S}, 606.0607$; found 606.0606 .

\section{Conclusions}

In conclusion, we have designed and synthesized new acceptors bearing halogen-substituted oxindoles for the application in DSSCs. Among all the halogen-substituted acceptors studied in this artical, the sensitizer with Br exhibited superior photo-physical properties. Also, the amide carbonyl groups of these acceptors can have partial chelation to the $\mathrm{TiO}_{2}$ surface providing an added benefit towards effective electron injection. The new oxindole building block can provided a new gateway for future rational dye design for applications in DSSC. Evidently, further enhancement in the absorption profiles of oxindole sensitizers can be obtained by using different electron withdrawing substituents and adding efficient donating moieties. Such structural modification of oxindole-based sensitizers to gain superior performances in DSSC is currently underway in our laboratory.

Supplementary Materials: The following are available online. Figure S1: Theoretical calculation for the location of HOMOs and LUMOs, Table S1: Bond lengths $[\AA ̊]$ and angles $\left[{ }^{\circ}\right]$ for ester $4 \mathbf{b}$, Table S2: Bond lengths $[\AA]$ and angles $\left[{ }^{\circ}\right]$ for ester 7 .

Author Contributions: Y.S.T. Conceptualization, performed the synthesis and wrote the manuscript.; C.S. validation, supervision and helped draft the manuscript.; M.-T.S. participated in the synthesis; S.-H.T. and S.-Y.H. carried out device characterization.; W.-R.L. validation, project administration and helped draft the manuscript. All authors have read and agreed to the published version of the manuscript.

Funding: We thank the Ministry of Science and Technology, ROC, for financial support (grants MOST 108-2113-M-027-002-MY, MOST 107-2113-M-027-004, and MOST 106-2113-M-008-007).

Conflicts of Interest: The authors declare no conflict of interest. 


\section{References}

1. Grätzel, M. Mesoscopic solar cells for electricity and hydrogen production from sunlight. Chem. Lett. 2005, 34, 8-13. [CrossRef]

2. Yun, S.; Lund, P.D.; Hinsch, A. Stability assessment of alternative platinum free counter electrodes for dye-sensitized solar cells. Energy Environ. Sci. 2015, 8, 3495-3514. [CrossRef]

3. Wu, J.; Lan, Z.; Lin, J.; Huang, M.; Huang, Y.; Fan, L.; Luo, G. Electrolytes in Dye-Sensitized Solar Cells. Chem. Rev. 2015, 115, 2136-2173. [CrossRef] [PubMed]

4. Sugathan, V.; John, E.; Sudhakar, K.J.R.; Reviews, S.E. Recent improvements in dye sensitized solar cells: A review. Renew. Sustain. Energy Rev. 2015, 52, 54-64. [CrossRef]

5. Docampo, P.; Guldin, S.; Leijtens, T.; Noel, N.K.; Steiner, U.; Snaith, H.J. Lessons Learned: From Dye-Sensitized Solar Cells to All-Solid-State Hybrid Devices. Adv. Mater. 2014, 26, 4013-4030. [CrossRef] [PubMed]

6. Zhang, S.; Yang, X.; Numata, Y.; Han, L. Highly efficient dye-sensitized solar cells: Progress and future challenges. Energy Environ. Sci. 2013, 6, 1443-1464. [CrossRef]

7. Grätzel, C.; Zakeeruddin, S.M. Recent trends in mesoscopic solar cells based on molecular and nanopigment light harvesters. Mater. Today 2013, 16, 11-18. [CrossRef]

8. Hardin, B.E.; Snaith, H.J.; McGehee, M.D. The renaissance of dye-sensitized solar cells. Nat. Photon. 2012, 6, 162-169. [CrossRef]

9. Hagfeldt, A.; Boschloo, G.; Sun, L.; Kloo, L.; Pettersson, H. Dye-Sensitized Solar Cells. Chem. Rev. 2010, 110, 6595-6663. [CrossRef]

10. Mishra, A.; Fischer, M.K.R.; Bäuerle, P. Metal-Free Organic Dyes for Dye-Sensitized Solar Cells: From Structure: Property Relationships to Design Rules. Angew. Chem. Int. Ed. 2009, 48, 2474-2499. [CrossRef]

11. Robertson, N. Optimizing Dyes for Dye-Sensitized Solar Cells. Angew. Chem. Int. Ed. 2006, 45, $2338-2345$. [CrossRef] [PubMed]

12. Nazeeruddin, M.K.; Grätzel, M. Comprehensive Coordination Chemistry II; McCleverty, J.A., Meyer, T.J., Eds.; Elsevier: Amsterdam, The Netherlands, 2003; Volume 9, Chapter 16.

13. Grätzel, M. Dye-sensitized solar cells. J. Photochem. Photobiol. C Photochem. Rev. 2003, 4, 145-153. [CrossRef]

14. Grätzel, M. Photoelectrochemical cells. Nature 2001, 414, 338-344. [CrossRef] [PubMed]

15. O’Regan, B.; Grätzel, M. A low-cost, high-efficiency solar cell based on dye-sensitized colloidal TiO2 films. Nature 1991, 353, 737-740. [CrossRef]

16. Maddah, H.A.; Berry, V.; Behura, S.K. Biomolecular photosensitizers for dye-sensitized solar cells: Recent developments and critical insights. Renew. Sustain. Energy Rev. 2020, 121, 109678. [CrossRef]

17. Boschloo, G. Improving the performance of dye-sensitized solar cells. Front. Chem. 2019, 7. [CrossRef]

18. Sharma, K.; Sharma, V.; Sharma, S.S. Dye-Sensitized Solar Cells: Fundamentals and Current Status. Nanoscale Res. Lett. 2018, 13, 381. [CrossRef]

19. Yin, J.-F.; Velayudham, M.; Bhattacharya, D.; Lin, H.-C.; Lu, K.-L. Structure optimization of ruthenium photosensitizers for efficient dye-sensitized solar cells-A goal toward a "bright" future. Coord. Chem. Rev. 2012, 256, 3008-3035. [CrossRef]

20. Robson, K.C.D.; Bomben, P.G.; Berlinguette, C.P. Cycloruthenated sensitizers: Improving the dye-sensitized solar cell with classical inorganic chemistry principles. Dalton Trans. 2012, 41, 7814-7829. [CrossRef]

21. Nazeeruddin, M.K.; Kay, A.; Rodicio, I.; Humphry-Baker, R.; Müller, E.; Liska, P.; Vlachopoulos, N.; Grätzel, M. Conversion of light to electricity by cis-X2bis(2,2'-bipyridyl-4,4'-dicarboxylate)ruthenium(II) charge-transfer sensitizers ( $\mathrm{X}=\mathrm{Cl}-, \mathrm{Br}-, \mathrm{I}-, \mathrm{CN}-$, and $\mathrm{SCN}-)$ on nanocrystalline titanium dioxide electrodes. J. Am. Chem. Soc. 1993, 115, 6382-6390. [CrossRef]

22. Nazeeruddin, M.K.; Péchy, P.; Renouard, T.; Zakeeruddin, S.M.; Humphry-Baker, R.; Comte, P.; Liska, P.; Cevey, L.; Costa, E.; Shklover, V.; et al. Engineering of Efficient Panchromatic Sensitizers for Nanocrystalline TiO2-Based Solar Cells. J. Am. Chem. Soc. 2001, 123, 1613-1624. [CrossRef] [PubMed]

23. Nazeeruddin, M.K.; Splivallo, R.; Liska, P.; Comte, P.; Grätzel, M. A swift dye uptake procedure for dye sensitized solar cells. Chem. Commun. 2003, 9, 1456-1457. [CrossRef] [PubMed]

24. Grätzel, M.J.J.o.P.; Chemistry, P.A. Conversion of sunlight to electric power by nanocrystalline dye-sensitized solar cells. J. Photochem. Photobiol. A 2004, 164, 3-14. [CrossRef] 
25. Nazeeruddin, M.K.; De Angelis, F.; Fantacci, S.; Selloni, A.; Viscardi, G.; Liska, P.; Ito, S.; Takeru, B.; Grätzel, M. Combined Experimental and DFT-TDDFT Computational Study of Photoelectrochemical Cell Ruthenium Sensitizers. J. Am. Chem. Soc. 2005, 127, 16835-16847. [CrossRef] [PubMed]

26. Yasuo, C.; Ashraful, I.; Yuki, W.; Ryoichi, K.; Naoki, K.; Liyuan, H. Dye-Sensitized Solar Cells with Conversion Efficiency of 11.1\%. Jpn. J. Appl. Phys. Part 1 2006, 45, L638.

27. Wang, S.-W.; Chou, C.-C.; Hu, F.-C.; Wu, K.-L.; Chi, Y.; Clifford, J.N.; Palomares, E.; Liu, S.-H.; Chou, P.-T.; Wei, T.-C.; et al. Panchromatic Ru(ii) sensitizers bearing single thiocyanate for high efficiency dye sensitized solar cells. J. Mater. Chem. A 2014, 2, 17618-17627. [CrossRef]

28. Jia, H.-L.; Li, S.-S.; Gong, B.-Q.; Gu, L.; Bao, Z.-L.; Guan, M.-Y. Efficient cosensitization of new organic dyes containing bipyridine anchors with porphyrins for dye-sensitized solar cells. Sustain. Energy Fuels 2020, 4, 347-353. [CrossRef]

29. Higashino, T.; Imahori, H. Porphyrins as excellent dyes for dye-sensitized solar cells: Recent developments and insights. Dalton Trans. 2015, 44, 448-463. [CrossRef]

30. Yella, A.; Mai, C.-L.; Zakeeruddin, S.M.; Chang, S.-N.; Hsieh, C.-H.; Yeh, C.-Y.; Grätzel, M. Molecular Engineering of Push-Pull Porphyrin Dyes for Highly Efficient Dye-Sensitized Solar Cells: The Role of Benzene Spacers. Angew. Chem. Int. Ed. 2014, 53, 2973-2977. [CrossRef]

31. Urbani, M.; Grätzel, M.; Nazeeruddin, M.K.; Torres, T. Meso-Substituted Porphyrins for Dye-Sensitized Solar Cells. Chem. Rev. 2014, 114, 12330-12396. [CrossRef]

32. Li, L.-L.; Diau, E.W.-G. Porphyrin-sensitized solar cells. Chem. Soc. Rev. 2013, 42, 291-304. [CrossRef] [PubMed]

33. Bessho, T.; Zakeeruddin, S.M.; Yeh, C.-Y.; Diau, E.W.-G.; Grätzel, M. Highly Efficient Mesoscopic Dye-Sensitized Solar Cells Based on Donor-Acceptor-Substituted Porphyrins. Angew. Chem. Int. Ed. 2010, 49, 6646-6649. [CrossRef] [PubMed]

34. Collavini, S.; Völker, S.F.; Delgado, J.L. Understanding the Outstanding Power Conversion Efficiency of Perovskite-Based Solar Cells. Angew. Chem. Int. Ed. 2015, 54, 9757-9759. [CrossRef] [PubMed]

35. Zhao, Y.; Zhu, K. Organic-inorganic hybrid lead halide perovskites for optoelectronic and electronic applications. Chem. Soc. Rev. 2016, 45, 655-689. [CrossRef]

36. Green, M.A.; Ho-Baillie, A.; Snaith, H.J. The emergence of perovskite solar cells. Nat. Photonics 2014, 8, 506-514. [CrossRef]

37. Rong, Y.; Liu, L.; Mei, A.; Li, X.; Han, H. Beyond Efficiency: The Challenge of Stability in Mesoscopic Perovskite Solar Cells. Adv. Energy Mater. 2015, 5, 1501066. [CrossRef]

38. Yen, Y.-S.; Chou, H.-H.; Chen, Y.-C.; Hsu, C.-Y.; Lin, J.T. Recent developments in molecule-based organic materials for dye-sensitized solar cells. J. Mater. Chem. 2012, 22, 8734-8747. [CrossRef]

39. Yao, Z.; Zhang, M.; Wu, H.; Yang, L.; Li, R.; Wang, P. Donor/Acceptor Indenoperylene Dye for Highly Efficient Organic Dye-Sensitized Solar Cells. J. Am. Chem. Soc. 2015, 137, 3799-3802. [CrossRef]

40. Wu, Y.; Zhu, W. Organic sensitizers from D-[small pi]-A to D-A-[small pi]-A: Effect of the internal electron-withdrawing units on molecular absorption, energy levels and photovoltaic performances. Chem. Soc. Rev. 2013, 42, 2039-2058. [CrossRef]

41. Kanaparthi, R.K.; Kandhadi, J.; Giribabu, L. Metal-free organic dyes for dye-sensitized solar cells: Recent advances. Tetrahedron 2012, 68, 8383-8393. [CrossRef]

42. Ooyama, Y.; Harima, Y. Molecular Designs and Syntheses of Organic Dyes for Dye-Sensitized Solar Cells. Eur. J. Org. Chem. 2009, 18, 2903-2934. [CrossRef]

43. Cong, J.; Yang, X.; Liu, J.; Zhao, J.; Hao, Y.; Wang, Y.; Sun, L. Nitro group as a new anchoring group for organic dyes in dye-sensitized solar cells. Chem. Commun. 2012, 48, 6663-6665. [CrossRef] [PubMed]

44. Rice, C.R.; Ward, M.D.; Nazeeruddin, M.K.; Grätzel, M. Catechol as an efficient anchoring group for attachment of ruthenium-polypyridine photosensitisers to solar cells based on nanocrystalline $\mathrm{TiO} 2$ films. New J. Chem. 2000, 24, 651-652. [CrossRef]

45. Nazeeruddin, M.K.; Zakeeruddin, S.M.; Humphry-Baker, R.; Jirousek, M.; Liska, P.; Vlachopoulos, N.; Shklover, V.; Fischer, C.-H.; Grätzel, M. Acid-Base Equilibria of (2,2'-Bipyridyl-4,4'-dicarboxylic acid)ruthenium(II) Complexes and the Effect of Protonation on Charge-Transfer Sensitization of Nanocrystalline Titania. Inorg. Chem. 1999, 38, 6298-6305. [CrossRef] 
46. Numata, Y.; Ashraful, I.; Shirai, Y.; Han, L. Preparation of donor-acceptor type organic dyes bearing various electron-withdrawing groups for dye-sensitized solar cell application. Chem. Commun. 2011, 47, 6159-6161. [CrossRef]

47. Delcamp, J.H.; Yella, A.; Nazeeruddin, M.K.; Grätzel, M. Modulating dye E(S+/S*) with efficient heterocyclic nitrogen containing acceptors for DSCs. Chem. Commun. 2012, 48, 2295-2297. [CrossRef]

48. Hong, J.; Lai, H.; Liu, Y.; Yuan, C.; Li, Y.; Liu, P.; Fang, Q. New organic dyes containing E- or Z-trifluoromethyl acrylic acid as the electron acceptors for dye-sensitized solar cell applications: An investigation of the effect of molecular configuration on the power conversion efficiency of the cells. RSC Adv. 2013, 3, 1069-1072. [CrossRef]

49. Li, T.-Y.; Su, C.; Akula, S.B.; Sun, W.-G.; Chien, H.-M.; Li, W.-R. New Pyridinium Ylide Dyes for Dye Sensitized Solar Cell Applications. Org. Lett. 2016, 18, 3386-3389. [CrossRef]

50. Silva, J.F.M.; Garden, S.J.; Pinto, A.C. The chemistry of isatins: A review from 1975 to 1999. J. Braz. Chem. Soc. 2001, 12, 273-324. [CrossRef]

51. Sun, L.; Tran, N.; Tang, F.; App, H.; Hirth, P.; McMahon, G.; Tang, C. Synthesis and Biological Evaluations of 3-Substituted Indolin-2-ones: A Novel Class of Tyrosine Kinase Inhibitors That Exhibit Selectivity toward Particular Receptor Tyrosine Kinases. J. Med. Chem. 1998, 41, 2588-2603. [CrossRef]

52. Marfat, A.; Robinson, R.P. Preparation of azaoxindole-1-carboxamides as antiinflammatories and analgesics. U.S. Patent 5,811,432 A, 22 September 1998.

53. Robinson, R.R.; Donahue, K.M.; Son, P.S.; Wagy, S.D. Synthesis of substituted azaoxindoles for the preparation of aza-tenidap analogs. J. Heterocyclic Chem. 1996, 33, 287-293. [CrossRef]

54. Tingare, Y.S.; Shen, M.-T.; Su, C.; Ho, S.-Y.; Tsai, S.-H.; Chen, B.-R.; Li, W.-R. Novel Oxindole Based Sensitizers: Synthesis and Application in Dye-Sensitized Solar Cells. Org. Lett. 2013, 15, 4292-4295. [CrossRef] [PubMed]

55. Simon, S.J.C.; Parlane, F.G.L.; Swords, W.B.; Kellett, C.W.; Du, C.; Lam, B.; Dean, R.K.; Hu, K.; Meyer, G.J.; Berlinguette, C.P. Halogen Bonding Promotes Higher Dye-Sensitized Solar Cell Photovoltages. J. Am. Chem. Soc. 2016, 138, 10406-10409. [CrossRef] [PubMed]

56. Yoder, N.C.; Kumar, K. Fluorinated amino acids in protein design and engineering. Chem. Soc. Rev. 2002, 31, 335-341. [CrossRef] [PubMed]

57. Babudri, F.; Farinola, G.M.; Naso, F.; Ragni, R. Fluorinated organic materials for electronic and optoelectronic applications: The role of the fluorine atom. Chem. Commun. 2007, 10, 1003-1022. [CrossRef] [PubMed]

58. Chen, B.-S.; Chen, D.-Y.; Chen, C.-L.; Hsu, C.-W.; Hsu, H.-C.; Wu, K.-L.; Liu, S.-H.; Chou, P.-T.; Chi, Y. Donor-acceptor dyes with fluorine substituted phenylene spacer for dye-sensitized solar cells. J. Mater. Chem. 2011, 21, 1937-1945. [CrossRef]

59. Bhim Raju, T.; Vaghasiya, J.V.; Afroz, M.A.; Soni, S.S.; Iyer, P.K. Design, synthesis and DSSC performance of o-fluorine substituted phenylene spacer sensitizers: Effect of TiO2 thickness variation. Phys. Chem. Chem. Phys. 2016, 18, 28485-28491. [CrossRef]

60. Jie, J.; Xu, Q.; Yang, G.; Feng, Y.; Zhang, B. Porphyrin sensitizers involving a fluorine-substituted benzothiadiazole as auxiliary acceptor and thiophene as $\pi$ bridge for use in dye-sensitized solar cells (DSSCs). Dyes Pigments 2020, 174, 107984. [CrossRef]

61. Mao, J.; He, N.; Ning, Z.; Zhang, Q.; Guo, F.; Chen, L.; Wu, W.; Hua, J.; Tian, H. Stable Dyes Containing Double Acceptors without COOH as Anchors for Highly Efficient Dye-Sensitized Solar Cells. Angew. Chem. 2012, 124, 10011-10014. [CrossRef]

62. Mann, J.R.; Gannon, M.K.; Fitzgibbons, T.C.; Detty, M.R.; Watson, D.F. Optimizing the Photocurrent Efficiency of Dye-Sensitized Solar Cells through the Controlled Aggregation of Chalcogenoxanthylium Dyes on Nanocrystalline Titania Films. J. Phys. Chem. C 2008, 112, 13057-13061. [CrossRef]

63. Kuang, D.; Uchida, S.; Humphry-Baker, R.; Zakeeruddin, S.M.; Grätzel, M. Organic Dye-Sensitized Ionic Liquid Based Solar Cells: Remarkable Enhancement in Performance through Molecular Design of Indoline Sensitizers. Angew. Chem. Int. Ed. 2008, 47, 1923-1927. [CrossRef] [PubMed]

64. Tian, H.; Yang, X.; Chen, R.; Pan, Y.; Li, L.; Hagfeldt, A.; Sun, L. Phenothiazine derivatives for efficient organic dye-sensitized solar cells. Chem. Commun. 2007, 36, 3741-3743. [CrossRef] [PubMed] 
65. Chen, R.; Yang, X.; Tian, H.; Sun, L. Tetrahydroquinoline dyes with different spacers for organic dye-sensitized solar cells. J. Photochem. Photobiol. A 2007, 189, 295-300. [CrossRef]

66. Hara, K.; Wang, Z.-S.; Sato, T.; Furube, A.; Katoh, R.; Sugihara, H.; Dan-oh, Y.; Kasada, C.; Shinpo, A.; Suga, S. Oligothiophene-Containing Coumarin Dyes for Efficient Dye-Sensitized Solar Cells. J. Phys. Chem. B 2005, 109, 15476-15482. [CrossRef]

67. Liu, W.-H.; Wu, I.C.; Lai, C.-H.; Lai, C.-H.; Chou, P.-T.; Li, Y.-T.; Chen, C.-L.; Hsu, Y.-Y.; Chi, Y. Simple organic molecules bearing a 3,4-ethylenedioxythiophene linker for efficient dye-sensitized solar cells. Chem. Commun. 2008, 41, 5152-5154. [CrossRef]

Sample Availability: Samples of the compounds not available from the authors.

(C) 2020 by the authors. Licensee MDPI, Basel, Switzerland. This article is an open access article distributed under the terms and conditions of the Creative Commons Attribution (CC BY) license (http://creativecommons.org/licenses/by/4.0/). 